Kenneth White

założyciel Międzynarodowego Instytutu Geopoetyki

emerytowany profesor

Université Paris-Sorbonne

\title{
Zarys geopoetyki
}

"Zasady i pierwiastki"

(Arystoteles)

Przez stulecia cywilizację napędzały różne siły, takie jak mit, religia, metafizyka. Ale chociaż pozostałości po nich jeszcze trwają - zazwyczaj zresztą $\mathrm{w}$ zdegradowanej postaci - dzisiejszej cywilizacji nie napędza już nic - po prostu rozrasta się i rozprzestrzenia niczym nowotwór.

Ostatnią siłą napędową była historia, jak dowodził Hegel, widząc w jej działaniu obecność „ducha świata” - Weltgeist.

Od czasów Hegla panowało przekonanie, iż historia jest rozumna, ma swój cel i dokądś prowadzi. Wtedy to narodziła się ideologia Postępu (której przyświecały Wzrost i Powodzenie w Interesach). Majaczące na horyzoncie „dokądś” przyjmowało różną postać w zależności od ideologicznego kontekstu. W Niemczech Ottona Bismarcka miała to być wszechwładza państwa co doprowadziło w końcu do nazistowskiej Drittes Reich („Trzeciej Rzeszy”, w znaczeniu trzeciego cesarstwa - po cesarstwie rzymskim i cesarstwie Karola Wielkiego). W marksistowskiej Rosji chodziło o stworzenie ogromnego Państwa, którego misją byłoby zniesienie wszystkich Państw i zapoczątkowanie Światowego Komunizmu. Jeśli chodzi o liberalny Zachód, celem byłoby coś w rodzaju gigantycznego Supermarketu, oferującego w promocji szczęście dla wszystkich (pod warunkiem, że pilnujesz swojego miejsca w kolejce i nie krytykujesz kierownictwa). Projekt bismarckowsko-nazistowski legł 
$\mathrm{w}$ gruzach razem ze spalonym Berlinem. Marksistowskie światło w tunelu zaczęło niknąć w ostatnich dekadach dwudziestego stulecia, aż w końcu ni stąd, ni zowąd zgasło. Na horyzoncie widnieje już tylko wielki Supermarket.

Mamy zatem Współczesną Sytuację. Pustkę, wypełnioną rosnącą liczbą obrazów i dźwięków. Triumfuje mediokracja - przeciętność urasta do poziomu społecznej i politycznej władzy. $\mathrm{W}$ istocie rzeczy wszędzie panuje bezmyślna bylejakość. Nic dziwnego, że literatura czy sztuka stanowią zaledwie odbicie tego stanu i sytuacji, w jakiej się znaleźliśmy.

Oczywiste stało się, że - jakiekolwiek by nie były ludzkie oczekiwania, nawet przelotne i przypadkowe, od nacjonalizmu, socjalizmu, narodowego socjalizmu, komunizmu, faszyzmu, liberalizmu - opisanej wyżej sytuacji nie da się rozwiązać przy użyciu politycznych narzędzi. Wszystko, co polityka na własną rękę może zrobić - i czego możemy od niej oczekiwać - to starać się w mniej lub bardziej kompetentny sposób radzić sobie z jej symptomami.

Podstawowe pytanie ma bowiem charakter raczej kulturowy niż polityczny - o ile, jak podkreśliłem, pojęcie kultury rozumiemy w sensie głębszym od potocznego.

Potocznie słowo „kultura” ma w naszych społeczeństwach znaczenie ściśle socjologiczne. Odnosi się do wszystkiego, co dzieje się w takich obszarach, jak teatr, kino, literatura, balet czy sztuki wizualne. Od czasu do czasu dokonywane są drobne rozróżnienia, jak na przykład między „kulturą elitarną" a "kulturą popularną"; ta pierwsza ma się odnosić do wytworów i działalności zużytych i dryfujących umysłów, ta druga natomiast, niewiele mając wspólnego z kulturą ludową, przypomina raczej coś w rodzaju papki, którą niektórzy społeczni „decydenci” obdarzeni mediokratycznym zmysłem uznali za odpowiednią dla pospólstwa i łatwą do sprzedania. Najczęściej jednak kultura jest terminem pozbawionym definicji, obejmującym wytwarzanie wszelkich przedmiotów i podejmowanie wszelkich aktywności, które mieszczą się poza sferą użyteczności i powiązane są z tzw. wolnym czasem. Koncepcja ta opiera się na przekonaniu, że im więcej dane społeczeństwo wytwarza książek, filmów, sztuk, obrazów, rzeźb, instalacji, koncertów itp. (to, co najlepsze czy najpotrzebniejsze gubi się w całym tym chaosie), tym bardziej jest rozwinięte. A przecież wcale tak nie jest. Prawdziwa ewolucja radzi sobie, gdy nawet jest tego znacznie mniej. Prawdę mówiąc, dzisiejsza kultura konsumencka koncentrująca się na przedmiotach, szaleńczo aktywna, zmierza donikąd, a marketingowe zarządzanie nią przeobraziło się w zwyczajny biznes, ślepy na jakiekolwiek poważniejsze intencje.

Pojawia się w związku z tym pytanie, czy jakiekolwiek „poważniejsze intencje" są jeszcze możliwe, czy wciąż możliwa jest prawdziwa zmiana czasów, cokolwiek, co otworzy nową epokę bycia. 
Właśnie w tym miejscu na scenę wchodzi geopoetyka, odpowiadając: być może.

Jawi się nam ona jako co najmniej piękny gest (ostatni może gest czującej i inteligentnej ludzkości?) i jako najbardziej interesująca z otaczających nas rzeczy.

Jeśli chcemy zdać sobie dokładnie sprawę z tego, gdzie się teraz znajdujemy, jeśli chcemy mieć wgląd w najzwyczajniejsze treści naszego umysłu, musimy przeprowadzić analizę postępu naszej (zachodniej) cywilizacji.

Proponowałbym spojrzeć na tę cywilizację jak na autostradę o wielu różnych etapach. Każdy $\mathrm{z}$ tych etapów pozostawił ślady $\mathrm{w}$ naszej świadomości. Wędrując nimi, będę stawiać pytania, na które właśnie geopoetyka może odpowiedzieć.

Pierwszy etap, Epokę Klasyczną, reprezentują Platon i Arystoteles, obaj wpisani w język, którym się posługujemy, w nasz sposób myślenia.

Platon wynalazł metafizykę, czyli idealizm. Kiedy mówimy o kimś, że jest „idealistą", brzmi to jak rodzaj komplementu. Chodzi o kogoś, kogo zajmuje coś więcej niż codzienne, „światowe” sprawy: Dobro, Prawda, Piękno. Jednocześnie jednak przemycamy $\mathrm{w}$ tym pewną krytykę: osoba ta powinna stanąć na twardym gruncie, wrócić „na ziemię", do "prawdziwego świata” (gdzie - kolejna implikacja - nikt się ani trochę nie przejmuje Dobrem, Prawdą i Pięknem).

Czy byłoby możliwe wyjście poza opozycję idealizmu i realizmu? Poza wszelkie próby udialektycznienia jej (jako np. ideorealizm)? A także poza niefrasobliwy nihilizm, który wchodzi na scenę, gdy tylko upadnie idealizm? Czy możliwe jest wyjście poza podział na to, co intelektualne, i to, co zmysłowe, podział, na którym opiera się metafizyka, a który nieuchronnie prowadzi do pustego intelektualizmu z jednej i sentymentalizmu z drugiej strony?

Jeśli chodzi o Arystotelesa, jego wkład w budowę Autostrady (przemarszu cywilizacji zachodniej) zasadzał się na klasyfikacji, taksonomii. Klasyfikacja to bardzo użyteczne narzędzie. Jeśli twoja biblioteczka liczy dziesięć książek, to nie masz problemu. Ale jeśli jest ich trzysta czy trzy tysiące, to bez takiej czy innej klasyfikacji będziesz tracić mnóstwo czasu. Poza tym utylitarnym aspektem klasyfikacja ma też wymiar epistemologiczny: opiera się na niej większa część naszej wiedzy. Dzielimy rzeczywistość na części i te części badamy. Na przykład martwe ciało kładziemy na stole i tniemy. Sporo się dzięki temu uczymy o układzie oddechowym, krwiobiegu, budowie naj- 
różniejszych organów. W przypadku dysfunkcji nasza medycyna leczy tę czy inną część. Może jednak pojawić się podejrzenie, że całość to więcej niż suma części, a żywa całość może funkcjonować w nieco inny sposób niż ten, jaki ukazuje sekcja, gdyż zdrowie nie zależy od leczenia poklasyfikowanych części, ale od całego organizmu funkcjonującego w określonym środowisku. I wreszcie, o ile klasyfikacje są użyteczne, to jednak mogą się stawać zbyt ciasne - wtedy realne, żywe życie świata i umysłu przepływa ponad nimi. Istnieją przecież książki, które nie mieszczą się w systemach gatunkowych większości historii literatury czy klasyfikacjach przedmiotowych większości księgarń. Geopoetyka sytuuje się - na jeszcze bardziej ogólnej płaszczyźnie - poza i ponad obecnie ustalonym i sklasyfikowanym podziałem na naukę, filozofię i poezję.

Po Epoce Klasycznej nadeszło tak zwane Średniowiecze - etap 2 naszej Autostrady, etap silnie naznaczony przez chrześcijaństwo. Choć życie płynęło wśród pól i ogrodów, co widać na przepięknych miniaturach ilustrujących osobiste modlitewniki, choć święty Franciszek niemal po pogańsku opiewał Brata Słońce i Siostrę Księżyc, choć zdarzały się ruchy odstępców i intelektualne herezje, chrześcijaństwo postrzegało świat doczesny jako padół łez, przez który trzeba przejść, dążąc do życia poza nim. Podkreślano wertykalny stosunek do transcendencji, upostaciowiony przez pnące się ku niebu kościelne wieże i zwieńczenia. Miejsce chwytanej intelektem Idei zajął Bóg, którego należało wielbić, bać się i kochać za pośrednictwem Dziewicy Maryi i Chrystusa. W miejscu Platońskiego rozumu czy Arystotelejskiej wiedzy pojawił się naznaczony obsesją Grzechu Pierworodnego psychologiczny teatr, a świat zaczęto cierpiętniczo umoralniać. Kolejną obsesją stał się czas. Skoro Chrystus Zbawiciel wstąpił do nieba po złożeniu siebie $\mathrm{w}$ ofierze, to kiedyś na pewno powróci na ziemię. Należy z nadzieją czekać na Jego Powtórne Przyjście. Jeśli nadzieja uleci, nadal będzie się czekało - na Godota.

Etap 3 kulturowej Autostrady to Renesans. Odrodzenie, narodzenie-na-nowo - czego? Epoki Klasycznej, klasycznej przestrzeni. Przede wszystkim w postaci dzieł Platona i Arystotelesa, zapomnianych w wiekach średnich i ocalonych dzięki uczonym arabskim. Następnie $\mathrm{w}$ formie mitologicznej, w postaci bogów i bogiń, najad i driad. Wszystkie te mityczne stworzenia już niebawem miały przypuścić prawdziwy szturm na umysły. Przez długi czas żaden godny tego miana poemat nie mógł obejść się bez jakiejś Wenus, Endymiona i tym podobnych, aż wreszcie - pod koniec dziewiętnastego wieku - porzucono je wszystkie jako wynaturzenie, kłopotliwy bagaż poprzedniej epoki. A przecież mityczne postacie początkowo służyły ważnym celom kulturalnym. Zanim stały się czystą konwencją, były funkcjonalne: 
leśna nimfa miała budzić zainteresowanie lasem, a muza z danej góry przyciągała uwagę ku górom. Świat przyrody znów budził zaciekawienie. Stąd właśnie wzrost roli nauki: jako próby wejrzenia w tajemnice natury. Stąd też zainteresowanie ziemskim światem i pragnienie odkrycia, co znajduje się poza granicami niewielkiego, za to „znanego świata” ze średniowiecznych map. Odkrywano nowe światy - przede wszystkim na Zachodzie - po drugiej stronie Atlantyku. Zwróćmy uwagę, co się wówczas okazało. Otóż znacznie łatwiej jest narzucić nieznanemu to, co znane, niż samemu otworzyć się na nieznane. Dlatego też wędrowcy przybywający na wyspę zamiast przyjrzeć się jej dokładnie i nazwać ją zgodnie z tym, co widzą (co byłoby aktem poetyckim, a nawet geopoetyckim), powiedzmy - „Wyspą Stromych Skał" czy "Wyspą Palmową" - chrzcili ją imieniem "Świętego Jana”, „Świętego Marcina", jakiegoś króla czy gubernatora. Zatykali flagę, eksterminowali wszystkich poprzednich mieszkańców, ludzi czy nie-ludzi. W efekcie tak zwany Nowy Świat nigdy nie był naprawdę nowy, a jedynie stanowił rozdętą karykaturę kilku części Starego Świata. Na pierwszy rzut oka odrodzenia wydają się pełne rozmaitych tonów. Nawet na głębszym poziomie, o ile niektórym umysłom uda się dotrzeć do tej nowo oświetlonej, nowo brzmiącej przestrzeni, większość z tego, co się dzieje, to w istocie powtórki: klasyczna filozofia nauczana w humanistycznych szkołach była zaledwie bladym odbiciem bardziej radykalnych obszarów myśli greckiej.

Wynaleziona przez Kartezjusza Nowoczesność (etap 4 Autostrady) była radykalna - radykalna i bezlitosna zarazem. Sprowadziła ona skomplikowaną istotę świata do opozycji podmiot - przedmiot, a podział na podmiot/przedmiot zrodził projekt zapanowania nad Naturą. Wraz z nastaniem nowoczesności Natura jest coraz bardziej uprzedmiotowiana, postrzegana wyłącznie jako surowiec do wyeksploatowania. Katastrofalne konsekwencje ekologiczne tej postawy są powszechnie znane. Co do podmiotu z kolei, to albo jest on kompletnie zrobotyzowany i opakowany w kliniczny, naukowy, astronautyczny czy wojskowy mundur, albo kończy na kozetce u psychoanalityka - gotujący się z frustracji, przepełniony fantazmatami: mentalnym kinem w każdym dającym się wyobrazić gatunku. Nowoczesność wciąż pędzi Autostradą.

Pierwsza reakcja pochodziła od czegoś, co nazwano Romantyzmem. Prywatne jednostki uprzytomniły sobie wówczas, że zostały ogołocone ze wszystkiego i usiłowały coś z tym zrobić. „Tym, czego szukacie, jest świat” - 
powiadał sam do siebie Hörderlinowski bohater, Hyperion (człowiek o hiperżądaniach). Oznaczało to przede wszystkim "powrót do Natury”, niekiedy tylko w kategoriach sentymentalnych, ale też próbę osiągnięcia swoistej pełni myślenia i bycia, która przybierała postać poszukiwań wykraczających poza ustanowione podziały wiedzy, odrzucających myślowe zaszufladkowanie. O ile psychologia, biologia czy fizyka w „porządnej” organizacji epistemologicznej stanowiły osobne wydziały, Romantycy próbowali myśleć w terminach syntetycznej złożoności: psychobiofizyki. Carlyle stworzył karykaturę Romantyka - dr Teufelsdröckha („Diablego smoka”), zainstalowanego na uniwersytecie pod nazwą Weissnichtwo („Bóg wie gdzie”) i rozprawiającego na temat badań transcendentalnych, symbolizmu (okien na nieskończoność) i naturalnej nadnaturalności.

Postacie, które gdzie indziej nazwałem „intelektualnymi nomadami”, nie są Romantykami, ale dzielą z nimi punkt wyjścia, wspólny kontekst; stawiają też po części te same pytania, jednak starają się znaleźć nowe odpowiedzi, a także próbują wyjść poza reaktywność w stronę nowego działania (aktywności).

Postacie te trudno zdefiniować, nie da się ich także poklasyfikować. Nie są profesjonalistami, ale nie są też amatorami. To nie osoby, to podmioty. Osoba społeczna to nagromadzenie dziedzictwa, zakodowanych emocji oraz fantazji. Podmiot nomadyczny to intencja i trajektoria. Osoba jest tożsamością. Podmiot to pole energii.

$\mathrm{Na}$ początku tej książki ${ }^{1}$ przyglądałem się dość szczegółowo posunięciom dwu takich postaci, a mianowicie Nietzschego i Rimbauda - ta dwójka odegrała szczególną rolę $\mathrm{w}$ mojej własnej trajektorii. Przypomnę o nich krótko, oświetlając dodatkowo kilka kwestii.

Nietzsche porzuca zawodową pozycję filologa klasycznego na Uniwersytecie w Bazylei. Od tego czasu niczym nomada przemierza Europę. Możemy prześledzić trasę jego wędrówki z Niemiec do Szwajcarii, ze Szwajcarii do Francji i Włoch: „Zdecydowałem się ruszyć w obce strony na spotkanie tego, co było mi obce... Zacząłem długą włóczęgę, wypełnioną poszukiwaniami i przemianami, której nie da się łatwo podsumować... Czujesz, jak przestrzeń wokół ciebie rośnie, a horyzont się otwiera...". W toku tych podróży po szczytach Nietzsche pisze całą serię elektryzujących książek, analizujących kontekst, jaki pozostawił za sobą, i zarysowujących nową przestrzeń, w której się znalazł: Ludzkie, zbyt ludzkie, Jutrzenka, Tako rzecze Zaratustra, Zmierzch bożyszcz, Ecce homo. Jego ostatnie słowa w obliczu wszelkich

\footnotetext{
1 The Wanderer and His Charts [przyp. red.].
} 
transcendentalnych wierzeń i technologicznego niszczenia ziemi brzmiały: „Zaklinam was, bracia, pozostańcie wierni ziemi".

W pobliżu Nietzschego pojawia się równie wpływowa postać, ktoś, kto dla poezji był tym, kim Nietzsche dla filozofii - zrywał więzy, desperacko szukając nowych przestrzeni. Rimbaud.

Choć Rimbaud pozostawił na scenie literackiej dwie książki: Sezon w piekle i Iluminacje, jego życie było przede wszystkim przemierzaniem różnych terytoriów. Pierwsze kroki prowadzą go przez region Ardenów - położony między północną Francją a Belgią. Później obserwujemy go zimą na Przełęczy Świętego Gotarda (,jedyne o czym da się myśleć, to biel”) między Szwajcarią a Włochami. Potem możemy prześledzić jego podróże przez Niemcy i Anglię. Następnie opuszcza Europę i udaje się do Indonezji. Wreszcie, na samym końcu, obserwujemy go na płaskowyżu Ogaden w Abisynii. W jednym z wierszy deklaruje: "Chęci teraz nabrałem / tylko na piach i kamienie”. Chciałbym to wyznanie zestawić z Nietzscheańskim „,bracia, pozostańcie wierni ziemi"; w obu tych zdaniach, tak jak w trajektoriach obu tych postaci, odnajduję bowiem podstawy geopoetyki.

Może wydawać się dziwne, dlaczego nigdy nie zainteresowałem się w tym samym stopniu żadnym $\mathrm{z}$ pisarzy angielskich. Po prostu $u$ żadnego angielskiego autora (może jedynie w niektórych fragmentach utworów D. H. Lawrence'a) nie dostrzegłem takiej egzystencjalnej energii, intelektualnej ostrości i poetyckiej siły, jaką odnalazłem u Francuza i Niemca.

To w tym kontekście należy odczytywać moją własną wędrówkę.

Opuściwszy Glasgow (które wówczas rozkwitało wszystkimi przejawami cywilizacji zachodniej w jej późnej fazie), mając w pamięci najwcześniejsze doświadczenia z atlantyckich wybrzeży Szkocji, podróżowałem przez Europę wraz z tomem Travels in the Drifting Dawn, przedostałem się do Azji z The Face of the East Wind, po czym przemierzyłem Amerykę Północną wraz z Blue Road. Z obszarów tych (globalnie rzecz ujmując, ,najtrudniejszego obszaru") narodziły się wiersze zawarte w kolejnych tomikach, od Walking the Coast, przez Handbook for the Diamond Country i Atlantica, aż po Limits and Margins, zebrane potem w tomie Open World. Po wędrówkach i wierszach nadszedł czas na eseje, które przez długi czas pisałem głównie po francusku, z tomów The Outward Movement, The Quiet Apocalypse, The Nomad Mind czy The Plateau of the Albatros, a więc próby przedstawienia nowej, poetycko-teoretycznej kartografii.

Teraz chcę zaproponować nie tyle podsumowanie tych esejów, co syntetyczną, a zarazem szczegółową prezentację różnych dopływów - naukowego, filozoficznego, poetyckiego - zasilających geopoetykę oraz krótki przegląd wierszy i książek wskazujących do niej drogę. 
Jakkolwiek dziecinna, wariacka i nieodpowiedzialna może się jawić geopoetykowi ta lub inna techno-nauka, nie ma żadnych wątpliwości, że wiele $\mathrm{z}$ tego, co działo się i wciąż dzieje $\mathrm{w}$ nauce $\mathrm{w}$ naturalny sposób przedostaje się również na pole geopoetyki.

Wśród najdalszych przodków geopoetyki mogę wymienić Aleksandra von Humboldta. W jednym z przypisów do swego Kosmosu Humboldt stwier$\mathrm{dza}$, że nauka, poezja i filozofia nie są $\mathrm{z}$ gruntu sobie obce i że $\mathrm{w}$ umyśle kogoś, kto osiągnął stan jedności, występują razem. Rzeczona jedność jest charakterystyczna dla "kompletnego dzieła” w znaczeniu, jakie nadaję temu terminowi. Podobna jedność może się pojawić, w szerszym ujęciu, w pewnych okresach historycznych. Jedną $z$ tez geopoetyki jest przekonanie, że my sami możemy stać się twórcami takiej właśnie epoki.

W wielu książkach naukowych opublikowanych w ciągu ostatnich dziesięciu, mniej więcej, lat pojawia się słowo "poetyka”, zwykle w ostatnim rozdziale. Dzieje się tak dlatego, że nauka osiągnęła obszary, w których „normalny" język wydaje się już nieadekwatny, a struktura rzeczywistości jawi się jako coś raczej poetyckiego niż mechanistycznego.

Wszystko zaczęło się od tekstu Einsteina Kosmologiczne rozważania nad ogólna teoria względności (1917). Nagle słowo „kosmos” na nowo zagościło w ludzkiej świadomości. Pojawił się jednocześnie naukowiec, którego nie zadowalało już proste mierzenie i ważenie ani polowanie na jakąś nową cząsteczkę; naukowiec występujący przeciwko uświęconemu aksjomatowi, że nie jest możliwa nauka o całości, a jedynie o częściach; naukowiec nie tylko rozprawiający o "całości”, ale używający na jej określenie greckiego słowa oznaczającego "piękną całość”.

Tekst ten $\mathrm{z}$ całą pewnością wyznacza pewien zwrot $\mathrm{w}$ nauce. Ale z punktu widzenia naszego krótkiego wprowadzenia do geopoetyki użyteczniej będzie zajrzeć do korespondencji Einsteina (zwłaszcza z Maxem Bornem), oferującej nam wgląd w sposób funkcjonowania tego naukowego umysłu i ukazującej naukowca zadającego sobie pytania natury egzystencjalnej i kulturalnej.

Przede wszystkim rzuca się w oczy szczególne podejście Einsteina do własnego życia: "Czuję się tak złączony z całością życia, że wydaje mi się niemożliwe określić, w którym miejscu zaczyna się lub kończy jednostka". Również jako naukowiec starał się lepiej uchwycić ów dylemat: rozdźwięk między schematami logiki a „urokliwością życia”. Jeśli celem ma być klarowność, absolutna klarowność, to jedynym adekwatnym językiem pozostaje matematyka. $Z$ drugiej strony jednak matematyka pomija tak wiele, 
że świat zostaje pozbawiony substancji i gubi się „,żywy kontekst”. Pojawia się w związku z tym pytanie: czy mimo tego dylematu, rozdźwięku, który w oczach Einsteina urósł do rangi tragedii, można w jakiś sposób pogodzić logiczną klarowność z „urokliwością życia”? Potrzebny do tego jest nowy rodzaj myślenia. Einstein mówił o własnym umyśle, że jest z natury „dziko spekulatywny” i podkreślał konieczność odsunięcia na bok „mechanicznej, wyspecjalizowanej logiki” w celu "ogromnego intelektualnego przeskoku”.

Właśnie tego rodzaju "przeskoki” widać w najżywszej od czasów Einsteina myśli naukowej. Nie chodzi tu jednak o skok z powrotem w metafizykę albo religię, jaki obserwujemy u niektórych naukowców, ale skok naprzód - wprost w pole niepewności i niezdefiniowania.

Zacznijmy od fizyki kwantowej, gdzie trafu, chaosu i nieokreśloności wcale nie uznaje się za momenty naruszenia porządku rzeczy, tylko za integralne elementy ruchomego uniwersum-multiwersum. Pojawia się w związku z tym nowa gramatyka, już nie gramatyka klasycznego porządku, lecz oparta na przepływach, nieregularności i złożoności.

W biologii z kolei Francisco Varela i Humberto Maturana zaczęli się posługiwać terminem „autopoetyka” na określenie działania skomplikowanych systemów zdolnych wykorzystywać porządek i nieporządek do strukturyzacji samych "siebie”.

I wreszcie (przynajmniej w tym szkicu) dochodzimy do wkładu, jaki miała w tym zakresie lingwistyka. W tej dziedzinie kluczową rolę umysłu zapładniającego inne umysły odgrywa Francuz Gustave Guillaume. Odsunął on na bok większość „naukowych” prac dotyczących języka, przyjmując, że jest to „maksimum wiedzy oparte na ograniczonym zrozumieniu”. Jako badacz języka Guillaume postawił dość radykalną tezę, że „człowiek istnieje nie tylko w kontekście ludzkim, ale i w kontekście wszechświata".

\section{5}

W obliczu nawału introwertycznego komplikowania, w jaki przerodziła się spora część filozofii późnej nowoczesności, wiele filozoficznie nastawionych umysłów dążyło raczej w kierunku etnologii, socjologii i innych nauk o człowieku, w obrębie których nie musiałyby zamykać się - jak wiele osób obszaru anglojęzycznego - w ciasnych ramach logicznego pozytywizmu. Mimo wszystko w obrębie samej filozofii również miał miejsce interesujący rozwój: w ewolucji tej nie brakowało ani radykalnych przemieszczeń, ani topologicznych transformacji.

Zaczęło się od Nietzschego. 
Nietzsche, doskonale poznawszy przyczółki akademickiej i klasycznej filozofii, postanowił je opuścić. Większość filozofii - stwierdził - zbudowana została na takim lub innym zahamowaniu. Dlatego właśnie zamiast stawiać poważne problemy $\mathrm{w}$ obrębie ciasnych struktur, zamiast dodawać kolejną cegiełkę do rozmaitych konstrukcji („Dlaczego mój intelekt jest tak ostry, rozeznanie tak przenikliwe? Ponieważ nie tracę czasu na stawianie pytań, które nie są prawdziwymi pytaniami".), podjął się radykalnej analizy kultury; zamiast pisać traktaty, pisał książki złożone z esejów, fragmentów, jednym słowem - nieustającą autobiografię.

Wychodząc poza rolę filozofa, Nietzsche wynalazł figurę filozofa-artysty (w moim słowniku będzie to „poeta-myśliciel”), pochylającego się zarówno nad szeroką koncepcją wyrastającą $\mathrm{z}$ „uniwersalnej symfonii” (poeta-myśliciel charakteryzowany jest przez „amplitudę i różnorodność”), jak i nad polem bezpośredniego doświadczenia, niezapośredniczonej percepcji.

Filozof-artysta to przede wszystkim samotny podróżnik, niezdolny do tego, by osiąść w wygodnym, udomowionym kontekście, ale niestrudzenie poszukujący miejsca, przestrzeni, gruntu, gdzie mógłby doświadczyć „ludzko-nadludzkiego błogostanu". Nietzsche przedzierał się przez pustkowie nihilizmu, starając się utorować sobie drogę powrotu poza metafizyką i wejść w taki krajobraz-myśloobraz, nad którym nie dominowałby żaden transcendentalny idol, żadna religijna ideologia. Starał się wyjść na zewnątrz historii metafizyki i religii, przejść do nowej intelektualno-egzystencjalnej geografii.

$\mathrm{W}$ jednym ze swoich wierszy (choć z taką mocą krytykował poezję, opierającą się na zahamowaniach i chorobie $\mathrm{w}$ takim samym stopniu jak większość filozofii, to jednak ten filozof-artysta sam pisywał wiersze, nazywając siebie „poetą na granicy słowa”) Nietzsche odmalowywał obraz kołującego na obrzeżach miasta stada kruków kraczących nad zimowym krajobrazem. Oto przedstawienie początku - ziemi i ruchu - w ujęciu radykalnego poety-myśliciela.

Na dzieło Nietzschego należy spoglądać jak na coś w rodzaju bicia skrzydłami $w$ coraz to szerszej i szerszej przestrzeni. Ale, jak powiada jeszcze gdzie indziej, im wyżej wzlatujesz, tym mniej ludzi cię widzi; tak samo zresztą nie rozumieją natury twojego dzieła po prostu dlatego, że nie wpasowuje się ono w utarte kategorie. W związku z tym Nietzsche był mniej lub bardziej pogodzony z niezrozumieniem za życia i jeszcze długo po śmierci - do momentu, gdy - jak już wspomniałem - uda się wykreślić mapę nowej przestrzeni poza epoką i światem (Sytuacją Współczesną), naznaczoną przez ruiny idealizmu, pozostałości po chrześcijaństwie, odrętwiały nihilizm, krótkowzroczny realizm i różne rodzaje uduchowienia, mniej lub bardziej graniczącego $\mathrm{z}$ wariactwem. 
Ostatnie przesłanie Nietzschego, wpatrzonego już w nowe otwarcie, skierowane było do innych samotnych wędrowców - mieli oni "pozostać wierni ziemi”, estetyce życia i kreatywności opierającej się na "przeczuciu, co będzie trwało, i niewielu środkach wyrazu".

Inny filozoficzny dopływ geopoetyki to dzieło Martina Heideggera, kolejnego mocno niezrozumianego myśliciela, obłożonego przez niektórych - nie najlepiej bądź wcale niezaznajomionych z jego pracami - anatemą ze względu na przelotne powiązania z narodowym socjalizmem. Nie próbuję tuszować politycznej pomyłki Heideggera - przeciwnie, staram się zobaczyć, $\mathrm{z}$ czego dokładnie $\mathrm{w}$ obrębie jego dzieła ta pomyłka mogła się wziąć. Zarazem jednak nie mam zamiaru traktować tej pomyłki jako pretekstu, który pozwalałby pominąć jedną z najciekawszych myśli w XX wieku.

Punktem wyjścia dla Heideggera jest obserwacja, że świat, świat jako zjawisko, świat jako przestrzeń życiowa, został sprowadzony do uniwersum narzędzi, składu sprzętów (na las patrzy się jak na drewno, na górę - jak na potencjalny kamieniołom), do społecznego kontekstu, w którym istoty ludzkie trwają bez żadnego pojęcia o świecie, o głębi bycia bez poczucia bycia-w-świecie (presence-on-earth). Tak wiele straciliśmy z oczu, o tak wielu rzeczach już nie myślimy, że w pewnych sytuacjach językowych brak nam słów na określenie takiej kondycji (stąd wielość zawiłych debat), w pewnych zaś kontekstach ideologicznych niedostateczny mentalny dystans czy zbyt bliska perspektywa nie pozwalają dostrzec, co jest czym, ani zmierzyć się intelektualnie z jakąkolwiek wartą tej nazwy zmianą.

Według Heideggera ta sytuacja stanowi punkt dojścia całego rozwoju myśli, który daje się wywieść z początków metafizyki. Filozofia jako metafizyka czy ontologia nigdy nie ujmowała wystarczająco głęboko kwestii bycia. Dlatego właśnie Heidegger porzucił filozofię na rzecz tego, co nazywał „myśleniem początków”. Ten rodzaj myślenia stara się zaczynać za każdym razem od podstaw, wybierając ścieżki, które nie prowadzą do oczywistych celów (prowadzące "donikąd"), ale potencjalnie mogą się otworzyć na polanę. Ścieżki te przebiegają w umyśle, ale zarazem są rzeczywiste, fizyczne. Heidegger pędził życie między seminarium na Uniwersytecie we Fryburgu a chatą w Szwarcwaldzie, od której promieniście rozchodziły się takie właśnie ścieżyny.

W swojej próbie wyjścia poza domenę filozofii w stronę „,bardziej źródłowych” obszarów, o jakich filozofia „nawet nie słyszała”, w swojej próbie wynalezienia adekwatnego języka, Heidegger zwracał się ku pierwszym myślicielom, głównie Grekom (choć znał również myśl Dalekiego Wschodu), ale także ku poetom, w szczególności ku Hölderlinowi i Rilkemu. Jego własne 
pisarstwo często przybliżało się do poezji, tak jak w tej notatce na temat stosunku między ziemią a światem:

\author{
Ziemio \\ chroń początki \\ świecie \\ nastuchuj brzmień \\ świecie \\ bądź wdzięczny ziemi \\ ziemio \\ pozdrawiaj świat.
}

\title{
6
}

Można napisać wierszowany tekst, który będzie uchodził za wiersz, mimo że nie posiada prawdziwego „brzmienia” w znaczeniu, jakie dopiero co przywołaliśmy, cytując Heideggera. Nietzschego interesowała wyłącznie poezja dążąca "do granic". Rimbauda interesowała radykalnie - lub w ogóle - bardzo niewielka część poezji; prawdziwa poezja pozostawała zawsze „daleko przed nami". Pociągały go „nowe teorie wnikające w nieznane miejsca”. W odniesieniu do takiego właśnie typu teorio-praktyki ja sam używam słowa „poetyka”. Obejmując poezję jako taką, ma ono także znacznie szersze zastosowanie. Odnosi się nie tylko do poezji jako formy literackiej, ale również do sztuki i muzyki - da się rozciągnąć również poza te dziedziny, na naukę czy nawet praktykę społeczną.

Jeśli dla Rimbauda poezja w większości była z gruntu pozbawiona znaczenia, to właśnie dlatego, że nie była ugruntowana: nie była niczym więcej aniżeli werbalnym graniem w pchełki, jej kontekst nie wykraczał poza osobiste lub społeczno-personalne sprawy. Z rzadka udawało się jej wydostać na szerszą przestrzeń. Można by nawet powiedzieć, że była to poezja bez poetyki. Równie dobrze dałoby się uznać (sięgając myślą daleko wstecz, do starodawnego dalekowschodniego rozróżnienia na "poezję, która ma świat”, i „poezję, która nie ma świata”), że była to poezja bez świata.

Geopoetyka w swoim specyficznie poetyckim aspekcie zrywa z platońsko-arystotelesowską teorią poiesis jako mimesis, choć teoria ta wciąż leży $\mathrm{u}$ podstaw praktyki literackiej jako takiej (reprodukcja, reprezentacja, refleksja: pisarstwo lustrzane), przechodząc w stronę obecności-w-świecie, do- 
świadczenia pola i terytorium, otwartości stylu, budując złożoną relację z kosmologiczną "poetyką" uniwersum.

Jeszcze nie udało nam się rozpoznać dobrze pola, możliwe jednak , że elementy geopoetyki da się odnaleźć u wielu najznaczniejszych i najsilniej oddziałujących poetów ostatnich dwóch stuleci.

Już Novalis mówił o „pisarstwie ziemi”, które da się odnaleźć na skrzydłach ptaka, na muszlach, w chmurach, w śniegu, na zboczach gór, w roślinach, w zwierzętach i w świetle na niebie, które może zostać elementem języka ludzkiej istoty.

Już Walt Whitman zarzekał się, że jest gotów odrzucić niemal wszystko, co większość ludzi utożsamia ze słowem "poezja” - osobistą uczuciowość, wyobraźnię, gładką prozodię, władzę metafory - jeśli tylko uda mu się wyrazić pomarszczenie fali, oddech oceanu. Whitmanowskie „przypływy i odpływy nieskończonego ruchu” w abstrakcyjnym ujęciu odsłaniają, via owo pole fal, energię hydrodynamiczną.

Innym znaczącym amerykańskim protogeopoetykiem poprzedniej epoki był Henry Thoreau, który w podróży do Ktaadn uwalniał się z okowów ideologii tożsamości i filozofii zdrowego rozsądku, dzień po dniu praktykując permanentną ekstrawagancję (w źródłowym znaczeniu tego słowa: łacińskie extra vagare - „wywędrować gdzieś”) i, zmierzając, podczas nieobmyślanej wyprawy na Cape Cod, wzdłuż wybrzeża Atlantyku („Można tam stać, mając całą Amerykę za sobą”) w stronę poetyckiej atopii.

Oto Rilke mówi nam o „czystej przestrzeni przed sobą” i deklaruje, iż jego projekt poetycki jest „przedstawieniem ogromu, różnorodności i kompletności świata pod postacią czystych dowodów”. Język tego ustępu jest niemal matematyczny, naukowy; przywodzi na myśl Einsteina. Związki z Einsteinowską uniwersalną tożsamością jawią się coraz wyraźniej, gdy tylko Rilke powie: „Przeżywam życie w rosnących kręgach”.

Oto myśl Ezry Pounda, który po okresie antykwarycznej nostalgii i faszyzującego futuryzmu zdaje sobie sprawę - za Waltem Whitmanem - że celem poezji, jeśli ma być warta swojej ceny, jest „stworzyć kosmos”.

Oto Charles Olson, który także jeździł wzdłuż atlantyckiego wybrzeża („Cypel przy brzegu morza”), zacząwszy od poszukiwania Melville'owskiej białuchy, potem studiując miejskie cywilizacje całego świata, by wreszcie dotrzeć do posthistorycznego, posthumanistycznego i pięknego konkretu otwartości świata; wejść w „otwartość, której nie udało się wybić badaczom”.

Nieco dalej w głębi lądu znajdziemy poletko uprawiane przez Williama Carlosa Williamsa, ciągnące się wzdłuż rzeki Passaic, poza obszar „stagnacji większości literatury", ku nowej koncepcji inteligencji poetyckiej. 
W Szkocji znajdziemy Hugh McDiarmida, który na swoich kamiennych kresach, z wysokości wydm dostrzegł pole, o którym niewielu tylko w kontekście języka angielskiego w ogóle miało jakiekolwiek pojęcie, pole, w które wstępował często, pięknie i przekonująco.

I wreszcie jest ona u Saint-Johna Persego, kiedy prawi on o „nowym pisarstwie zamkniętym w łupku”, kiedy prosi morze, by nauczyło go „najważniejszego wiersza największego porządku”, ",tonacji największej sztuki”, modelu „największego z tekstów”.

\section{7}

Na koniec zajmijmy się kwestią słownictwa i języka.

Po pierwsze, dlaczego nazywamy to ogromne pole kulturowej pracy "geopoetyką"?

Jeżeli przyjrzeć się kulturom, które ludzkość rozwinęła na całej planecie, da się zauważyć, że wszystkie ogniskują się wokół jednego, głównego motywu (indukującego motywacje i sprzyjającego działaniu), wokół jednego centralnego wątku. W kulturze paleolitycznej był to stosunek do zwierząt (cały wachlarz kwestii, począwszy od utrzymywania się przy życiu, aż po mity). W kulturze chińskiej będzie to kosmiczna koncentryczność potęgi i mocy. W kulturze greckiej - płaszczyzna polityki miasta-państwa. W średniowiecznej kulturze Zachodu będzie to Dziewica Maria i Chrystus. Pytanie brzmi więc: jaki może być centralny motyw, podstawowy wątek światowej kultury - światokultury - dzisiaj? Taki, który mogą dzielić wszyscy, na Północy, na Południu, na Wschodzie i na Zachodzie? Rozsądek podpowiada oczywistą odpowiedź: sama Ziemia, na której staramy się żyć. Stąd właśnie przedrostek geo- w geopoetyce.

Jeśli chodzi natomiast o „poetykę".... Trudno powiedzieć, by słowo „poetyka" było dla kogokolwiek zobowiązujące (jeśli już, to pojawia się w zdewaluowanej formie) na końcowym etapie Autostrady, którą właśnie opisaliśmy. Nie stanowi też integralnej części słownika Technokracji/Mediokracji. Jeśli jednak raz jeszcze przyjrzymy się kulturom całego świata, kulturom żywym i ożywiającym, płodnym i trwałym, to zobaczymy, że w ich rdzeniu zawsze tkwiła poetyka. W kulturze paleolitycznej istniała figura szamana, którego poetyka zasadzała się na podtrzymywaniu kontaktu między ludzką społecznością a szerszym, pozaludzkim środowiskiem. W kulturze chińskiej istnieje Księga pieśni, po której stronicach hula „wicher terytoriów”. W greckiej kulturze będzie to oceaniczna poetyka Homera, bez której kultura ta byłaby kulawa, bez której płaszczyzna polityki byłaby oschła i powierzchowna. 
Od samego początku częścią mojego indywidualnego programu - i częścią programu geopoetyki od chwili jej poczęcia - było wypracowanie ekwiwalentu przywołanych przed chwilą poetyk dla świata (poetyki światowania). Aby uchwycić pełnię znaczenia i siłę tego słowa, sugeruję, byśmy cofnęli się do Arystotelesa i jego nous poietikos (czynnego "umysłu poetyckiego"). Chodzi bowiem o to, że geopoetyka to coś więcej aniżeli „poezja zajmująca się środowiskiem", coś więcej niż literatura zawierająca takie lub inne treści geograficzne (tak samo jak to, co nazywam „księgami drogi", to coś znacznie więcej niż literatura podróżnicza). Geopoetyka z zasady zajmuje się stosunkiem do Ziemi i otwieraniem świata.

O ile nie wypowiemy go bardzo wyraźnie, słowo "geopoetyka" będzie się często myliło ze słowem "geopolityka", które obecnie jest znacznie szerzej znane i używane. Niech ta fonetyczna jukstapozycja będzie dla nas jeszcze jedną okazją do przedstawienia definicji. Geopolityka zajmuje się stosunkami władzy i potęgi między jednym a drugim państwem w skali globalnej, a przestrzeń postrzega wyłącznie w kategoriach zasobów do eksploatowania. Geopoetyka to znacznie głębsze i bardziej radykalne przedsięwzięcie. Tematem jej nie są terytorialne przepychanki o władzę między państwami, ale kondycja istoty ludzkiej we wszechświecie, relacja między człowiekiem a planetą Ziemią, obecność w świecie. Geopoetyka to antidotum na zatruwanie świata.

"Świat" - oto kolejne trudne pojęcie wykorzystywane na wielu różnych poziomach, często bez specjalnej finezji. W anglosaskim obszarze leksykalnym ma ono etymologię germańską i można je połączyć z czymś w rodzaju wer-alt, co oznacza, ni mniej, ni więcej, „wiek człowieka”. Właśnie to znaczenie „świata”, jako szczególnego etapu cywilizacyjnego, specyficznej konfiguracji społecznej miał na myśli Wordsworth, mówiąc, że "Świat, to za wiele...", i wyrażając tym samym pragnienie jakiegoś pojemniejszego sensu bycia, bardziej ekspansywnego kontaktu ze wszechświatem. Właśnie od tego rodzaju świata ludzie uciekają $w$ osobiste światy fantazji, gdyż zbyt często ich przytłacza i ogranicza. To dlatego szukają ulgi w światach natury religijnej albo po prostu rzucają się $\mathrm{w}$ pierwszą z brzegu rozrywkę.

Czy dałoby się (gdy tylko zaczynamy wnikać głębiej, natychmiast pojawiają się pytania) wyobrazić sobie świat nieprzekodowany, "otwarty”, taki, który nie jest tylko światem prywatnym, nie jest zaświatowy i oferuje coś więcej niż zajęcie dla zmysłów?

Zanim spróbujemy na tym etapie sformułować jakąkolwiek odpowiedź, skupmy się jeszcze przez chwilę na etymologii.

W językach romańskich w słowie określającym „świat” (po francusku monde, po hiszpańsku mundo, po włosku mondo) kryje się sens estetyczny, na- 
wiązujący do łacińskiego słowa mundus, ześrodkowany na płodnych współzależnościach, na zawęźlaniu komunikujących się sił. Z punktu widzenia postępu cywilizacyjnego istotny wydaje się fakt, że owo estetyczne znaczenie zachowało się tylko w ujęciu negatywnym, np. we francuskim określeniu immonde, oznaczającym coś "obrzydliwego i odpychającego". Podobnie też angielszczyzna zachowała korzeń mundus tylko w słowie "mundane", określającym coś "płaskiego i nieinteresującego".

Słowo "kosmos" również źródłowo posiadało konotacje estetyczne, oznaczając w starożytnej grece "piękną i harmonijną całość". Ten estetyczny sens utrzymał się już tylko w słowie "kosmetyk”. Może jednak najwyższy czas, byśmy wrócili do owego szerokiego kontekstu i bardziej ekstensywnych konotacji?

Mając w pamięci powyższe definicje, możemy zadać sobie pytanie o to, jak przejść - $\mathrm{w}$ pierwszym rzędzie konceptualnie - na pole życia?

Odchodząc od etymologii w stronę aktywnej terminologii i myśli, która działa, proponuję, co następuje: świat wyłania się w kontakcie między istotą ludzką a kosmosem, który reprezentuje Ziemia. Jeżeli kontakt ten jest świadomy, czuły i subtelny, otrzymujemy świat w jego pełnym i pozytywnym znaczeniu zadowalającego, satysfakcjonującego kontekstu, interesującego miejsca, które wzbogaca nasze życie. Jeśli jednak kontakt ten jest nieinteligentny, bez wyczucia, nieokrzesany i niezręczny, wówczas zamiast świata mamy zubożały kontekst, o ile nie przedsionek piekła.

Oczywiście do zubożonego kontekstu można się przyzwyczaić (istota ludzka charakteryzująca się nieprawdopodobnymi zdolnościami adaptacyjnymi może się przyzwyczaić niemal do wszystkiego), można się z nim identyfikować, można się na niego uodpornić dzięki zażyłości, lokalnemu patriotyzmowi itd. Można nawet perwersyjnie, z rozpaczy wywołanej nieustającą zmiennością rzeczy i otwieraniem się szerszych kontekstów, zdecydować się na wywyższanie i zwielokrotnianie owych okropności.

Geopoetyka każe nam natomiast skupić się na tym, by szerszy kontekst pozostawał zawsze otwarty. Bez poczucia owego szerszego kontekstu nawet wola społecznej zmiany (przez reformy lub rewolucje) może funkcjonować tylko w wąskich koleinach, co zresztą wielokrotnie już mieliśmy okazję zaobserwować, i prowadzić do sytuacji, które często okazywały się gorsze niż kontekst wyjściowy.

Świat to miejsce, przestrzeń, którą się uprawia. Aby dorosnąć do zadania, jakim jest uprawa świata, trzeba też uprawiać, kultywować siebie samego.

I w ten sposób wracamy do przeklętego i jakże często nadużywanego słowa „kultura”. 
Proponowana $\mathrm{w}$ obrębie geopoetyki robocza definicja kultury $\mathrm{w}$ kontekście jednostki (zaczynamy od jednostki, gdyż zawsze umie się ona poruszać szybciej niż społeczeństwo) brzmi następująco: jest to sposób, w jaki istoty ludzkie postrzegają siebie, pracują nad sobą i samymi sobą sterują. Kultura zakłada pewną koncepcję człowieka. I tak, człowieka postrzegano jako „stworzonego na boskie podobieństwo” (np. w chrześcijaństwie) albo „pana i władcy nad przyrodą" (w Nowożytności). W miejsce tych definicji proponuję „mieszkańca Ziemi”, a dokładniej - „poetyckiego mieszkańca Ziemi” (mając w pamięci Hörderlinowskiego „człowieka, który poetycko zamieszkuje na Ziemi"). Po nakreśleniu tej ogólnej koncepcji nadchodzi czas na pracę. Nie ma prawdziwej kultury bez pracy. Jeśli rolnictwo, agrokultura, oznacza pracę na roli, wspomaganie jej w wydaniu jak najlepszych plonów, to ludzka kultura oznacza pracę nad tym, by jednostka wzrastała w jak najdoskonalszej harmonii. Oto, nareszcie, pojawia się przed nami jakiś kierunek: przeczucie jakiegoś horyzontu możliwości.

Kultura w sensie wspólnotowym zaczyna się wtedy, kiedy w danej grupie jednostek - plemieniu, narodzie, wspólnocie - pojawia się zgoda co do spraw najistotniejszych.

Wracając do słowa „świat”... We wciąż toczącej się debacie między napędzanym siłą komercji międzynarodowym globalizmem $\mathrm{z}$ jednej strony a lokalizmem sprzęgniętym $\mathrm{z}$ ideologią tożsamości, wąsko pojętym nacjonalizmem, sekciarstwem i prowincjonalnym samozadowoleniem - z drugiej, geopoetyka nie opowiada się po żadnej ze stron. Dla geopoetyki "śswiat" to świat otwarty. Otwarty świat zaczyna się od miejsca, lecz nie od prostego przywiązania do miejsca (od poczucia domowej wspólnoty po upiorny animizm rodzący się z uprzedzeń rasowych), a od wiedzy (świadomej, czującej i inteligentnej) o miejscu. Każde miejsce, dogłębnie poznane, okazuje się otwarte. Od najmniejszego strumyka przez sieć rzeczną docieramy do oceanu. Nieco geologii pozwala zdać sobie sprawę, że nie wszystkie kamienie na lokalnej plaży pochodzą z okolicy - być może lodowce przyniosły je tu skądinąd. Podobnie warstwa lokalnej skały może być początkiem podróży przez wiele państw i kontynentów. Zorientowane oko, spoglądając na niebo, zobaczy nie tylko pędzone wiatrem chmury, ale i szlaki ptaków migrujących. Do tego wszystkiego koniecznie trzeba też dodać wędrówki ludów i języków.

W ten sposób dochodzimy do kolejnego aspektu światokultury, potencjalnie wyłaniającego się właśnie z ogromnego pola pracy: chodzi o ugruntowany uniwersalizm. W kontekście braku skupienia, lęków i pustki charakterystycznych dla ostatniego etapu Autostrady, ludzie poszukujący bardziej spójnej przestrzeni nawracają się na cokolwiek; sami zresztą widzimy, jak 
wiele jest rodzajów i gatunków nawróceń. W tej sytuacji znajdują się osoby, które są przekonane, że pracują na rzecz światokultury, organizując ekumeniczne zloty. Tego typu spotkania mogą zapewne wzmocnić ducha wzajemnej tolerancji - rzecz nie do pogardzenia w dzisiejszej rzeczywistości łatwego szczęścia - jednak ogólnie rzecz biorąc, brak w tym aktywnej i radykalnej roboty. Intelektualny nomada po opuszczeniu monolinearnej, monokulturowej i monomaniakalnej Autostrady przejdzie przez tyle kultur, ile tylko możliwe, nie poddając się relatywistycznej („ty w swoim kąciku, ja w swoim”), pluralistycznej („im więcej, tym weselej”) wizji spraw. W rzeczywistości bowiem każda kultura jest stronnicza. Dana kultura będzie kładła nacisk na jeden konkretny aspekt istoty ludzkiej, zaniedbując inne. Na przykład kultura Zachodu podkreśla uspołecznienie (,„żaden człowiek nie jest wyspą”), a kultura Wschodu akcentuje raczej potencjał rozwoju osobowości (buddyjskie: „bądź wyspą wewnątrz samego siebie").

Zadaniem intelektualnego nomady jest przejście przez wiele różnych kultur, by w końcu dotrzeć do jednej potencjalnej światokultury. Zadaniem geopoetyka jest zintegrowanie wielu aspektów różnych kultur tak, by wytworzyły one nowy rodzaj spójności. Ta nowa spójność nie traci swojej różnobarwności. Błyskają w niej wszelakie lokalne zabarwienia i odcienie. Obowiązujący sens jedności, który funkcjonuje na gruncie geopoetyki, ma wiele wspólnego $\mathrm{z}$ archipelagiem.

Na koniec musimy powiedzieć, że w ujęciu geopoetyki świat jest połączony z Ziemią. Niektórym wydaje się to oczywiste samo przez się, niemal niewarte zastanowienia ani, tym bardziej, przemyśleń. Innym może się to wydać krótkowzroczne i wsteczne. Dla ludzi tego rodzaju Ziemia jest czymś małym, anachronizmem, rzeczą o niewielkim znaczeniu lub zgoła go pozbawioną. Oni myślą już w kategoriach przestrzeni kosmicznej. Chcą budować miasta w kosmosie. Chcą skolonizować Marsa i inne, bardziej oddalone planety. Może człowiek nie jest do nich biologicznie przystosowany, ale od kiedy to jest przeszkodą? Na niektórych planetach wygodniej byłoby mierzyć ze trzy metry, ale pozostać chudziutkim, na innych - mieć metr wysokości i co najmniej tyle samo w obwodzie. To przecież żaden problem, wystarczy trochę manipulacji genetycznych. Geopoetyk jednak wie, że na gruncie biologii i innych dziedzin wiedzy optymalne warunki harmonijnego rozwoju człowieka panują właśnie tutaj, na Ziemi. Perspektywa ta wcale nie zamyka oczu na kosmos, ani go nie zapoznaje - zanim doszedłem do "geopoetyki", posługiwałem się słowem "biokosmopoetyka”. Fakt pozostaje faktem: żyjąc na Ziemi, istniejemy w kosmosie; można jednak być w kosmosie (w specjalnym kombinezonie i kapsule) i pozostawać kompletnie odłączonym. Jeśli chodzi o połączenie między światem a Zie- 
mią, między istotą ludzką a jej ziemsko-kosmicznym kontekstem, to, jak już powiedzieliśmy wcześniej, bardzo rzadko zdarza się go w pełni doświadczyć, w pełni przemyśleć czy w pełni wyrazić - i to właśnie stanowi cel geopoetyki.

Geopoetyka wymaga więc nowego wysłowienia, nowego działania, nowego światowania.

Tłumaczyła Agata Czarnacka

Tłumaczenie przejrzała Bogumiła Kaniewska

\section{An Outline of Geopoetics}

\section{Summary}

In the essay geopoetics is proposed as a viable cultural project. First, the author presents synthetically the various - scientific, philosophical, poetic - affluents to geopoetics which the poems and waybooks incorporate and carry. Then he explains the etymology and meaning of the term, pointing out that geopoetics is concerned with the state of the human being in the universe, the relationship between the human being and the planet Earth, and presence in the world. 
